\title{
A Holy Exchange: The Dedicatory Epistle of Clément Marot's Translation of the Psalms
}

\author{
GREGORY P. HAAKE
}

University of Notre Dame

Clément Marot, poet and evangelical sympathizer, published his own translation of thirty psalms in 1541, which in itself was not remarkable at the time. However, what distinguishes this collection is the dedicatory epistle that precedes it. Marot does more than flatter the king, to whom he dedicates his work, or introduce the text that follows. In this article, I argue that Marot composes a dedicatory epistle that, while following contemporary conventions of the genre, takes advantage of those conventions to accomplish a specific evangelical goal in a complex and sensitive religious and political environment. The text creates a typical exchange between patron and poet-the patron's protection in return for the poet's gift of the text-but Marot ultimately intends to bypass his patron and bestow a more profound gift upon the French people by way of this exchange, namely, to further a more evangelical scriptural approach and devotional practice.

Clément Marot, poète et sympathisant de la cause évangélique, a publié sa propre traduction de trente psaumes en 1541, ce qui n'était pas en soi un phénomène remarquable à cette époque. Cette collection se distingue cependant par l'épître dédicatoire qui la précède. Marot ne se contente pas de flatter le roi à qui il dédie cet ouvrage, ni même d'introduire le texte qui va suivre. Dans cet article, je me propose de démontrer que Marot a composé un épitre dédicatoire qui, tout en se pliant aux conventions contemporaines de ce genre, met ces dernières à profit pour accomplir un but évangélique dans un environnement religieux et politique à la fois délicat et complexe. Ce texte donne lieu à un échange de faveurs typique entre un mécène et un poète - le mécène offre sa protection au poète, qui lui fait cadeau d'un texte - mais Marot a pour but d'outrepasser son mécène en transformant cet échange en un cadeau au peuple français, c'est-à-dire en favorisant une approche plus évangélique et scripturale des pratiques dévotionnelles.

Cément Marot (1496-1544) had something to offer his king, François I $\mathrm{I}^{\mathrm{er}}$ usual course of exchange between the poet and his patron; in the past, Marot had come more than once to François with hand outstretched, asking for favours both material and legal. In his 1532 epistle, "Au Roy, pour avoir esté desrobé," Marot asks the king for restitution after his Gascon valet, "Gourmant, Yvroigne, \& asseuré Menteur, / Pipeur, Larron, Jureur, Blasphemateur” (vv. 8-10), had 
robbed him of all his possessions. ${ }^{1}$ In short, this rapscallion, in perpetrating his theft, "n'oublya rien, fors à [lui] dire Adieu" (v. 36). Marot succeeds in making his case to the king and receives the sum of 100 écus a little over a month later. ${ }^{2}$ In matters legal, Marot had requested from François five years earlier, in 1527, his release from prison. In the epistle, "Marot, Prisonnier, escript au Roy pour sa delivrance," the poet writes from jail, where he landed after intervening in the arrest by a watchman of an unnamed personage. The king granted Marot's request, and the poet obtained his own freedom within fifteen days. ${ }^{3}$ In both of these cases, Marot sees his requests fulfilled, but at what price? One of the models of the epistolary genre in the sixteenth century requires that the patron be reimbursed for his trouble. Pierre Fabri (1450-1535) articulates a concise definition of these parameters in his Le grand et vrai art de pleine rhétorique (1521): "Il est assavoir que en lettres missives et presque en toutes, l'en faict tousjours demande; et, pour justement demander, il est requis de demonstrer sa petition estre juste; secondement, estre possible a celuy a qui on demande en luy exposant la possibilité; tiercement, assigner la remuneration." ${ }^{4}$ While Marot does not always precisely follow this model in composing the entirety of his epistles, these two examples illustrate instances in which the poet makes an appeal for what he considers a just and feasible quid pro quo. In the case of his imprisonment, Marot promises in exchange nothing more than to stay out of trouble and an apology for not appearing in person to pay reverence to his sovereign, a duty that he cannot of course fulfill since he has yet to receive the freedom that he requires. In the case of his material misfortune, Marot relies upon his then more established literary reputation and pledges to write the king a "belle Cedulle" (v. 98), a promise of repayment in the form of the political capital created when the poet uses his verse to burnish the royal image and reputation. ${ }^{5}$ In either case, the writer of the epistle gains much more from his

1. Clément Marot, "Au Roy, pour avoir esté desrobé," in Les Epîtres, ed. C. A. Mayer (London: Athlone Press, 1958), 171-76. Verse citations appear in text.

2. C. A. Mayer, ed., Les Epîtres (London: Athlone Press, 1958), 171n1.

3. See Mayer, Les Epîtres, 132n1.

4. Pierre Fabri, Le grand et vrai art de pleine rhétorique, ed. Alexandre Héron (Geneva: Slatkine, 1969), 1:203.

5. See Cynthia Skenazi, "L'Economie du don et le mécénat: les formes de l'échange dans une épître de Clément Marot," French Studies 57.4 (October 2003): 463-74. Skenazi writes, "Le poème de Marot 
patron than he offers in return, thus exposing both the relative imbalance of the exchange and the understanding that its conditions are mostly rhetorical. ${ }^{6}$

Given the status of the respective parties, this imbalance and the tolerance thereof are not that surprising. In fact, it might even have a certain advantage if the epistle is also a dedicatory one. In "Clém. Marot, Au Roy Treschrestien Francoys, premier du nom," the dedicatory epistle that precedes Marot's 1541 translation of thirty psalms, the author-or in this case, translator-of the text acknowledges that he has the weaker position and therefore relies upon the patron's relative strength in seeking the favour of the patron's protection against potential attacks on the text or on the translator himself. In requesting this particular benefit, Marot places himself firmly within the traditions of the epistle in general, but also within those of the letter of dedication. ${ }^{7}$ This time, while he has yet to be imprisoned or robbed, he very well might be, especially since Marot's precise goals in translating the psalms more or less correspond to the fears of the keepers of orthodoxy who were regularly prosecuting those translating Scripture into the vernacular. ${ }^{8}$ When Marot had begun the translation of the psalms in 1531, he, along with Guillaume Briçonnet (1472-1534), Bishop of Meaux, and Marguerite de Navarre (1492-1549), the king's sister, hoped that it would contribute to the evangelization of France. ${ }^{9}$ Marot proposes to translate a pivotal text not only in the light of both reason and faith but also in a way that blends the scriptural with the devotional, an approach that reflects the Protestant emphasis on the biblical text as the centre of Christian worship and

permet par conséquent à son auteur de renégocier une dette anticipée (une dette d'argent et une dette affective) envers le roi par le biais d'une dépense conçue en termes esthétiques et culturels" (470).

6. For a discussion of what to do in the case of such an imbalance, see Fabri, 1:204. He writes, "[C]ar se ung povre demandea ung riche qui luy preste de l'argent, il n'est ja besoing de declarer sa demande estre juste, mais de necessité contrainte, ne de declarer sa possbilité et richesse, mais le louer de vertu liberalle par laquelle il subvient aux indigens."

7. See Demmy Verbeke and Jeanine De Landtsheer, "Letters of Dedication," in Brill's Encyclopaedia of Neo-Latin, ed. Jan Bloemendal and Charles Fantazzi (Leiden: Brill, 2014), 1034-36, 1035.

8. For a series of individual cases of prosecution of humanists or translators as heretics that François opposed, see James K. Farge, Orthodoxy and Reform in Early Reformation France: The Faculty of Theology of Paris, 1500-1543 (Leiden: Brill, 1985), 170-77.

9. For an account of how Marot decided to translate the psalms and of the timeline, see Gérard Defaux, introduction to Cinquante pseaumes de David, mis en francoys selon la vérité hébraïque, by Clément Marot (Paris: Honoré Champion, 1995), 5-69, 18-36. Defaux insists that Marot sought to make of himself an "instrumentum Dei, à mettre sa plume et sa muse au service de l'église du Christ" (19). 
study. ${ }^{10}$ Jacques Lefèvre d'Étaples (ca. 1450-1536), one of those persecuted for his translation of Scripture, provides a model for Marot in the prefatory epistle to his own translation of the psalms from 1524: "[N] ous avons mys ledict sainct livre en langaige vulgaire, affin que ceulx et celles qui parlent et entendent ce langaige puissent plus devotement et par meilleure affection prier dieu, et qu'ilz entendent aucunement ce qu'ilz prient, comme ilz font en plusieurs nations." ${ }^{11}$ Marot would have certainly agreed and likely had the chance to discuss it with Lefèvre d'Étaples. ${ }^{12}$

In his own dedicatory epistle, Marot is more coy, presumably to avoid incurring the accusations and trials that his predecessors had endured. This is not Marot the flatterer or the court poet, or even the poet of the ferme amour. ${ }^{13}$ This is Marot the poet and evangelizer, who is entering into a complex and delicate religious and political dance. At first glance, he produces a standard dedicatory epistle that includes many of the typical tropes: praise or flattery of the dedicatee, the relevance of the text to the dedicatee and to other potential readers, and a request for a favour. ${ }^{14}$ Marot's higher purpose, however, means that the "épître marotique" will yet again be characterized by its uniqueness, or by its unpredictability with respect to established norms. ${ }^{15}$ The conventions of the dedicatory epistle allow Marot a traditional structure within which to hold all of this together, that is, his relationship to François, a defense of the aesthetic and poetic value of the psalms in translation, and the navigation of the political and religious environment. And yet, as is his wont, Marot pushes beyond these limits, offering a gift that is meant to accomplish much more than the payment

10. For a discussion of the Psalter's role in the struggle for hearts and minds from a confessional point of view, see Catherine Reuben, La Traduction des psaumes de David par Clément Marot (Paris: Honoré Champion, 2000), 17. Reuben writes, "[Les psaumes] furent d'une importance primordial dans la lutte pour le cœur et la raison du people.”

11. Jacques Lefèvre d'Etaples, Les choses continues en ce present livre. Une epistre comment on doibt prier Dieu. Le psaultier de David: Pour trouver les sept pseaulmes accoustumez, qui a devotion de les dire. Argument brief sur chascun psealume pour Chrestiennement prier et entendre aucunement ce que on prie (Paris: Simon de Colines, 1524), as reprinted in Eugene F. Rice, Jr., ed., The Prefatory Epistles of Jacques Lefèvre d'Etaples and Related Texts (New York: Columbia University Press, 1972), 469.

12. See C. A. Mayer, La Religion de Marot (Geneva: Droz, 1960), 50.

13. For the opposition of these "two Marots," see Defaux, introduction to Cinquante pseaumes, 8.

14. Verbeke and De Landtsheer, 1034-35.

15. See Mayer, introduction to Epîtres, 32-39. Mayer even entitles this section, "L'Epître marotique." 
on a proposed exchange with his patron. Marot offers his psalm translation to the king in exchange for the king's protection, while fully intending that his offering will be received beyond the king. It will perform an evangelical function as an instrument of devotion rooted in Scripture for all people of faith.

\section{A worthy patron}

Any mention of the Psalter almost always evokes its author, King David, and this is precisely the image around which Marot will construct his treatment of François within his dedicatory epistle. At first glance, it may seem like simple and formulaic flattery, but the poet's comparisons between François and David serve rather to establish the very possibility of the exchange that Marot proposes. In other words, François must possess the desire and power to protect the text that the poet is dedicating to him, and the assimilation to David should both elicit this desire and also demonstrate the king's capacity and obligation to defend the translation. Marot suggests the connection between the two sovereigns beginning with the title of the 1541 text: Trente Pseaulmes de David, mis en francoys par Clement Marot, valet de chambre du Roy. This appellation is unremarkable, but it unites textually all of the parties involved and sets up what is to follow in the opening lines of the dedicatory epistle. He writes, "Tant est c'est [sic] œuvre \& Royal \& Chrestien, / Que de soymesme il se dit estre tien."16 Many authors and poets have already assimilated François with David, and some in even greater detail than Marot will be doing. ${ }^{17}$ In this instance, though, Marot mentions two central characteristics of the Psalter to argue the very natural and logical character of the assimilation between David and François, as well as the very natural and logical affinity that François should have for this particular scriptural text. The royal and Christian character of the Psalter, as well as the centrality of King David, makes for a logical connection to François, a

16. “Clem. Marot, Au Roy Treschrestien Francoys, premier du nom," in Trente Pseaulmes de David, mis en françoys par Clément Marot, valet de chambre du roy (Paris: Estienne Roffet, 1541), vv. 5-6 (Bibliothèque nationale de France (BnF) A-6165) (hereafter cited in the text). The apostrophe in the demonstrative pronoun in verse 5 seems to be a printing error that was corrected in the 1543 edition. See Clément Marot, Cinquante pseaumes de David, ed. Gérard Defaux (Paris: Honoré Champion, 1995), 95.

17. See, for example, Pauline M. Smith and Dana Bentley-Cranch, "A New Iconographical Addition to Francis I's Adoption of the Persona of King David and Its Contemporary Literary Context," Renaissance Studies 21.5 (2007): 608-24; or Anne Lake Prescott, "From the Sheephook to the Scepter: The Ambiguities of David's Rise to the Throne," Renaissance Quarterly 65.1 (2012): 1-30. 
suggestion that Marot sees as self-evident because it is so strong. Under normal circumstances, one might be tempted to think that the voice of Marot, the court flatterer, is quickly emerging, especially since Marot makes this comparison by emphasizing the great degree to which the psalms are Christian. The psalms are "Royal \& Chrestien," just like the Roi Très Chrétien. While there is no doubt that, coming from the mouth of King David, they are certainly royal, the psalms are still a part of the Hebrew scriptures. Nevertheless, Christians interpret them as a prophetic work that announces the coming of Jesus Christ, not only through David, Christ's kingly ancestor and predecessor, but also on a textual level in, for example, Marot's translation of Psalm 2: “[T]u es mon trescher filz eleu / Engendré t'ay au jourdhuy \& sans mere." ${ }^{18}$ This Christological hermeneutic, not new in any way to the Christian tradition, will become very important to the discussion of the psalms as a devotional text, but for now, it happens to serve the poet's purpose of suggesting an almost causal relationship between his translation and France's sovereign: the work that follows belongs to François because it is royal and Christian. Moreover, in citing these two particular characteristics of the work, which indeed appropriately reflect the nature of the Psalter, Marot establishes that his translation relates to both politics and religion, two domains in which the king would of course have competency. The psalms bridge the gap between David's roles as a political leader and as a prophet, a dual role that Marot implicitly attributes to François through the extensive comparison between the two that he then initiates:

Et qui es Roy, non de moindre renom

Que cestuy-la, qui meu du sainct esprit

A le dicter \& le chanter se prit. (vv. 8-10)

Marot is about to elevate François above an ancient political and religious leader who, he notes, enjoyed divine inspiration in creating a scriptural text. While this contention veers toward the hyperbolic, François's resemblance will in turn allow the poet to encourage the king's affection for a translation that corresponds so deeply to his role as both the Roi Très Chrétien and the père des lettres. ${ }^{19}$

18. Marot, Trente Pseaulmes de David, Psalm 2.7.

19. See Nancy Lyman Roelker, One King, One Faith: The Parlement of Paris and the Reformations of the Sixteenth Century (Berkeley: University of California Press, 1996), 191. Roelker discusses these two 
What at first seems an equal comparison between the ancient and contemporary kings- "non de moindre renom" would seem to put the two on an equal level-actually contains slight but significant variations in the qualities he attributes to the two men:

Car il fut Roy de prudence vestu,

Et tu es Roy tout aorné de vertu.

Dieu le donna aux peuples Hebraiques,

Dieu te devoit (ce pense je) aux Galliques,

Il estoit Roy, des siens fort honnoré,

Tu es des tiens (peu s'en fault) adoré.

Fort bien porta ses fortunes adverses,

Fort constamment les tiennes tu renverses. (vv. 15-20)

The distinctions at the heart of these comparisons establish in the end François's superiority over David, not just an equivalency. For example, David is only vested in prudence, one of the many virtues, while François is adorned in virtue in general. On both counts, he exceeds David's qualities, since adornment certainly implies more prestige than simple investiture and a general statement on virtue certainly encompasses more than simple prudence. Similarly, Marot leaves little doubt that being duty-bound to the Gauls supersedes being given to the Hebrews. ${ }^{20}$ While David's people honoured him, François's adore him. The next comparison attributes this same intensity to both kings' efforts in the face of adversity, but the end result differs in degree: "Fort bien porta ses fortunes adverses, / Fort constamment les tiennes tu renverses" (vv. 21-22). The repetition of the adverbial intensifier "fort" at the beginning of each verse that

attributions for the king in the context of his seemingly ambiguous approach to reformers. For a brief discussion of the title, Roi Très Chrétien, in the epistle, see Ehsan Ahmed, Clément Marot: The Mirror of the Prince (Charlottesville: Rookwood, 2005), 54-55.

20. Marot could also be making a political statement here related to the value of the French language as a vehicle for conveying spiritual meaning. See Marie-Luce Demonet, Les Voix du signe: Nature et origine du langage à la Renaissance (1480-1580) (Paris: H. Champion, 1992). Demonet writes, "La traduction des Psaumes par Marot renforce aussi l'égalité des langues, et notamment celle du français par rapport à l'hébreu ; en prenant appui sur la langue d'origine, Marot ne retourne pas à la langue originelle mais s'inscrit dans ce même espoir syncrétiste qui animait Münster en ajoutant une autre langue 'sacrée', le français" (173). 
modifies the subsequent adverb doubles as an evocation of strength, and while David endures his poor fortunes well, François has victory in the face of his, reversing them completely. Moreover, the mention of fortune, even if it is not as the allegory, connotes François's power even over a force that usually manifests indifference to human will.

Marot's cleverness accomplishes his goal of reassuring François that he resembles very much the ancient and holy king. From a visual standpoint, Marot often repeats at least one word in the two corresponding lines of his comparisons-"Roy/Roy" (vv. 15-16), "Dieu/Dieu" (vv. 17-18), and "Fort/ Fort" (vv. 21-22) - but at the same time, his rhetoric ensures that the great Christian king of the French eclipses his biblical predecessor in virtue and as a ruler. ${ }^{21}$ While one might be tempted to attribute the subtle elevation of François above David as the conventional obligation to compliment the dedicatee, this language simultaneously takes into account the tumultuous history of those who have suffered for vernacular translations of Scripture and anticipates the adversity that Marot's own text will face. The assertion that François surpasses David does not degrade the Hebrew king; it emphasizes rather the difference in the respective rulers' kingly missions. At a fundamental level, one governed the Hebrews and one governs the Gauls, but in the face of the possible suppression or persecution of the mid-sixteenth century, Marot reminds François of his capacity to overcome any obstacle in any context. The recent past suggests that when it comes to this particular type of text, those obstacles could be formidable.

Lest he go too far, Marot puts the two kings back on an equal level from this point forward. At the level of content, this happens to be the moment at which Marot more explicitly addresses David's and François's political and religious leadership. David entrusts himself and his work to God; François does similarly (vv. 25-26). David obtains peace by God's grace; François wants peace badly enough that he successfully acquires it (vv. 27-28). ${ }^{22}$ What more can he say? In fact, that is precisely the question that Marot poses before uniting the two kings at the level of the text; the first two words after this rhetorical

21. For an alternative reading of this passage, see Ahmed, 56. Ahmed proposes that the equivalence between David and François emphasizes the appropriateness of the psalm text as a gift for François, and also for France as a "second Israel."

22. See Defaux, Cinquante pseaumes, 229n2, where Defaux suggests a connection to the peace that François had obtained with Charles V in 1538. 
question are, "vous [pl.] estes." For the next ten verses, Marot addresses the two kings as a unit, beginning and ending with a statement upholding their immortal reputation, first in their political and military prowess and last in their writings (vv. 29-38).

Here ends Marot's discussion of David and François together, both of whose renown is founded upon their reputation as political leaders and as poets. Marot's assimilation of François and David reaches its climax in their love for the Muses and in the force of their writings. Implied in Marot's evocation of David's writings are the psalms, whose poetic but also religious character seals David's immortal role as a man of letters and an instrument of divine inspiration. David embodies the two roles in a seamless complementarity that Marot translates into an image not only to which François might aspire, but also to which François can compare his own poetic prowess and by which he can judge himself worthy. The image of François as a new David suggests an evolution in the identity of the poet-king from David's time to the present, and François embodies that role. The psalm text-or at least Marot's and others' perception of it-has also evolved, and Marot's praise of François invests the king with the interest, responsibility, and authority to cherish and protect this scriptural text that Marot now seeks to translate into a special status.

\section{A worthy gift}

Now that Marot has demonstrated that François's protection of his psalm translation is possible, in accordance with Fabri's second condition, he justifies his proposed exchange with his patron by affirming the value of the gift he offers. The text will constitute remuneration for services potentially rendered and therefore must be shown a sufficient recompense. Marot's strategy will be surprisingly comprehensive and methodical relative to the length of the epistle, involving comparisons between the psalms and the revered poetry of multiple eras. Marot's offer of payment begins with a direct command to François to take up the work of David, whose name is now mentioned for the first time: "O doncques roy, prens l'œuvre de David" (v. 39). It is no coincidence that this insistent request comes after the poet's assimilation of the two kings; Marot's "doncques" suggests that he sees this next step as a logical conclusion to the mirror images of François and David that have preceded it. Moreover, it reinforces the shift in the emphasis of the epistle from a discussion of the 
relationship between François and David to a discussion of the psalm text itself and of its worthiness as a devotional and aesthetic text. ${ }^{23}$ With Marot's encouragement to François to ponder the work of David, the work of a king and poet so like himself, Marot begins to demonstrate how, in the proposed exchange between poet and patron, he will make good on his obligations with a translation that merits the king's protection, as the Roi Très Chrétien and the père des lettres. Marot's argument involves more equivalencies, but this time, because they are centred on the text, they hinge on the process of poetic creation, or even inspiration:

Euvre plustost de Dieu qui le ravit,

D’autant que Dieu son Apollo estoit,

Qui luy en train \& sa harpe mettoit.

Le sainct esprit estoit sa Caliope,

Son Parnasus montaigne à double croppe

Fut le sommet du hault ciel cristalin :

Finablement, son ruisseau Cabalin

De grace fut la fontaine profonde,

Ou à grans traictz il beut de la claire unde,

Dont il devint le Poete en ung moment,

Le plus profond de soubz le firmament. (vv. 40-50)

Marot moves beyond David as an image that highlights François's strengths and now uses the Hebrew king to valorize the psalm text. As he did with his one-to-one comparison of David and François, Marot seems almost as if he were giving a word-for-word translation through which the sacred mirrors the profane and the focus is on David as a producer of poetry. God is David's Apollo; the Holy Spirit his Calliope, the first of the Muses and she who was responsible for epic poetry; Parnassus, the occasional home of the Muses and a site sacred to them, his heaven; and his font of grace, the Caballin stream-or as it is more traditionally known, the Hippocrene-that surges forth as Pegasus touches down upon the earth. Marot delineates the typical structure under which poets create their verse and then affixes Christian labels upon it. It is no

23. This was a value that Lefèvre d'Étaples had also expressed, namely, that piety can and should be eloquent. See Eugene F. Rice, introduction to The Prefatory Epistles of Jacques Lefèvre d'Étaples and Related Texts (New York: Columbia University Press, 1972), xix. 
wonder that Marot found himself in trouble with the guardians of orthodoxy, for the way in which Marot arranges the text seems to give precedence to the pagan as the standard by which one might judge the psalms. But this depends on the direction in which Marot is intending to translate his characterization of poetic creation, that is, from the sacred to the profane, or vice versa. The last two verses suggest that it is the latter: it is David who, in a moment, became the most profound poet under the firmament. The conclusion that François is to draw, therefore, is clear: the pagan language of inspiration does not lie in opposition to the poetic creation of God's chosen king and author of the psalms. In fact, what was for David the inspired writing of the divine word is not disconnected from pagan poetry but a more profound version of it.

In elevating psalmic poetry above the secular tradition, Marot is making a strong case for its aesthetic integrity. Before his validation, albeit mitigated, of the pagan and its lexicon becomes another reason to condemn him, Marot then makes very clear exactly what kind of poetic text he has chosen to translate for François. Through an extended preterition, Marot cites all the different types of poetry that the psalms are not, implying a comparison that leaves pagan poetry wanting. He begins with two well-known works from antiquity: "Icy n'est pas ladventure de AEnée. / Ne d'Achilles la vie demenée” (vv. 53-58). Marot emphasizes the distinction between the psalms and epic poetry by being sure not to actually mention the titles of the epics, nor their authors. What the two periphrases of both the Aeneid and the Iliad do mention, however, are the names of their respective heroes. Marot is able to simultaneously suggest of the psalms that they are wholly unlike these illustrious Greek and Roman epics, and evoke the hero of the psalms who is indeed unlike both Aeneas and Achilles. With David as their purported author, and Christ, as Marot's translation will make clear, as the hero, the psalms can stand with and apart from the venerated epic tradition. This is a work that is "bien autre qu'humain" (v. 52). While François is to surmise that Marot thinks it divine, these further statements declaring that his work of translation distinguishes itself from the poetry of circumstance, or even from epic, signal a shift toward a different level of poetic expression.

As verse, the psalms nevertheless retain their poetic character, a nature proper to them, which Marot's comparison to great lyric poetry affirms. The lyre, as a symbol closely associated with David, seals the relationship of the psalms to the lyric tradition. If the psalms can compete with Homer and his epic (vv. 115-18), they can also easily compete with Horace and his lyric: 
Pas ne fault doncq qu'aupres de luy Orace

Se mette en jeu, s'il ne veult perdre grace,

Car par sus luy vole nostre Poëte

Comme seroit l'aigle sus l'alouette

Soit à escrire en beaulx lyriques vers,

Soit à toucher la lyre en sons divers. (vv. 129-34)

The poet's labour of translation becomes once again evident; he is rendering into the vernacular a sacred text, but also an exceedingly beautiful one. David writes in the tradition of Horace, but he does it better. ${ }^{24}$ The exquisite verses that so many lyric poets from the Renaissance attempt emerge in David's poetry as well. In fact, these verses serve as a model. Marot's invocation of Horace, who should dare not compete with David, represents the beginning of the epistle's climax, for here Marot makes his final and most complete case that the psalms represent a sanctified version of the lyric. He makes a list of the other great figures revered in the Renaissance lyric tradition, and he declares that their respective lyres will all fail to compete, whether it be Orpheus, Arion, or Phoebus himself, who, after hearing David's poetry, would break his own lyre into pieces and cede his laurel to the poet of the psalms (vv. 141-46).

Finally, the great prize of Renaissance lyric appears, but it is only as he ends his dedicatory epistle that Marot names the laurel outright. Earlier in his epistle, Marot alludes to it only by its notable absence while he goes about asserting that the psalms can indeed be judged by contemporary aesthetic standards as well. That which Marot translates differs from the verse of the past, but it also builds on it. He points out to his patron how the psalms incorporate the principles that have come to define poetry in the Renaissance but that are not at all opposed to them either. While the exquisite verse may well lead to the eternal glory of salvation, the possibility for eternal poetic glory remains. François's relationship to and protection of the text would certainly allow him to profit from both. Marot writes,

24. For more on the Horatian influence on devotional poetry, see Terence Cave, Devotional Poetry in France c. 1570-1613 (Cambridge: Cambridge University Press, 1969), 58-59. While obviously focused on a later period, Cave's discussion of the Pléaide and the Counter-Reformation's engagement with Horace's idea of the utile dulci perhaps illustrates the development of Marot's preoccupation with respect to the psalms as devotional poetry. 
Et trouveras (sire) que sa couronne,

Ne celle la qui ton chef environne,

N'est mieulx ne plus de gemmes entournée,

Que son œuvre est de figures aornée. (vv. 119-22)

As he continues with his comparison to other poetry, Marot begins to personify the psalms. Their poetry has its own beauty and is ornamented as a crown. The psalms enjoy a rhetorical ornamentation-what is meant by "figures," as in rhetorical figures - that corresponds to even the gems that feature in François's kingly crown. This image allows Marot to hint at the poetic glory of the laurel that the psalms indeed enjoy while at the same time evoking the religious and political character of the text. Marot then amplifies the poetic glory that he attributes to the psalms in giving them the ability to bestow glory on their author:

Tu trouveras le sens en estre tel

Qu'il rend la hault son David immortel,

Et immortel ca bas, son livre, pource

Que l'eternel en est premiere source,

Et voulentiers toutes choses retiennent

Le naturel du lieu dont elles viennent. (vv. 123-28)

David, who was, of course, human, has become immortal thanks to the poetry he was inspired to write. This is not an immortality like that of Petrarch; it is not eternal poetic glory that the laurel signifies. Rather, it is eternal life. Marot's antithesis between David's current status up above and the presence of the book of psalms here below highlights the enduring nature of the text that, while it may look human, has its origins from among the divine. There can no longer be any question of the aesthetic value of the psalms; they could be evaluated according to any standards of the poetic arts and found worthy. And yet, something about this admirable aesthetic character opens the possibility of an even greater reward, not only for François, but for France. While the translation may constitute more than adequate compensation for the protection that the poet requires, the calibre of the text allows it to carry the weight of Marot's evangelical project. The psalms' subject matter and the character of their divine 
inspiration are exemplary of a text that will translate this poetic beauty into Christian devotion if only they can survive the many challenges of the religious and political atmosphere of France in the 1540s.

\section{A worthy cause}

The aggrandizement of the psalm text, aesthetically and otherwise, accompanied by the image of François as David, creates a forceful tone throughout Marot's epistle, and both of these would amply justify his petition to his king under normal circumstances. Moreover, both movements of the text seem to eclipse real concerns about potential censorship, a typical motivation for writers composing the dedicatory letter. In its complexity, Marot's appeal to François exceeds such a modest consideration. Remuneration, protection, justification: Fabri's terms might be said to constrain Marot's fuller and more edifying ends. Through his translation, a verse greater than lyric poetry unfolds, and François will exercise a role greater than simple protector. The Roi Très Chrétien will fulfil said role but in an unexpected fashion, namely, as the unwitting facilitator of Marot's evangelical designs. Ironically, Marot will bypass his patron despite the breathless comparisons to David and despite Marot's apparent need for François's religious and political power. The epistle lives up to its classification as "marotique," therefore, since Marot pushes the limits of the genre and writes not just to offer a gift that might be pleasing to his patron but to further a cause whose importance supersedes him. He takes advantage of the king's authority while claiming his own as he proposes to put readers of his translation into a more direct relationship to Scripture and to Christ. In relying on the conventions of the epistle and the dedicatory letter, Marot is able to conceal his direct appeal to a wider readership and to build in another layer of protection for the text by drawing a minimal amount of attention to his real purpose and its consequences. Nevertheless, the epistle still alludes to what the psalm translation will do, and it will not remain untouched by controversy. Hoping to ensure the success of his cause, Marot demonstrates the power of his translation to bring Christ to the reader, a function that happens to give the text its own standing in the face of the resistance that it will surely meet.

Early in his epistle, Marot begins to hint at the spiritual power of the text as he elevates the text's ability to please aesthetically to an even more meaningful level. Amid the aforementioned elucidation of what the psalms are not, the poet 
writes, "Ses vers divins, ses chansons mesurées, / Plaisent (sans plus) aux ames bien heurées" (vv. 59-60). Highlighting the capacity of these divine verses to give pleasure suggests that one can and should judge biblical poetry with the same aesthetic criteria as the secular, but in connecting that pleasure to joyful souls, he hints at the higher purpose that he hopes his translation will eventually achieve. ${ }^{25}$ The beauty of the psalmic verse both masks and serves a theological end that the poet later expresses when he expands his understanding of his intended audience. He writes,

O gentilz cueurs, \& ames amoureuses,

( $S$ 'il en fut oncq) quand serez langoureuses

D’infirmité, prison, peché, soucy,

Perte, ou opprobre, arrestez vous icy,

Espece n'est de tribulation

Qui n'ait icy sa consolation. (vv. 107-12)

Marot newly evokes the popular poetry of the time: poetry of circumstance that appeals to the noble hearts and praises their deeds, as well as lyric love poetry that resonates with hearts in love. While that poetry also has the power to please, the psalms perform a function that goes deeper toward the power to console in the midst of tribulation. Whatever ails the soul, the psalms can serve as a remedy: "C'est ung jardin plain d'herbes, \& racines, / Ou de tous maulx se trouvent medecines" (vv. 113-14). This particular assertion is rife with theological meaning while being stated in humanistic terms. The garden of grasses and roots reflects the language of humanistic medicine, but at the same time one can read the "maulx" as both sicknesses and evils. Marot, therefore, makes a theological argument about the nature of the consolation that the psalms offer the reader. These sacred verses are soothing because they are pleasing in a humanistic sense; they resemble the florilegium, a collection of beautiful verse plucked from the poetic garden. But they exceed that by offering a consolation infused with salvific grace, since the mention of the garden where

25. Marot had indeed succeeded in this, according to Calvin himself who preferred Marot's translation of the psalms over his own. See Reuben, 17-18: “[Calvin] n'aurait pas encouragé l'œuvre de Marot au dépens de sa propre traduction si lui-même et ses collègues n'avaient pas été convaincus que celle-là fut non seulement dramatiquement supérieure mais encore propice à promouvoir et populariser la cause de la Réforme." 
these medicines grow might also refer to the Garden of Eden, whose grace, before the coming of Christ, was closed off to fallen humanity.

The psalms can open a way back to this paradisaical state, and the possibility of their devotional use facilitates the return. Anticipating the criticism that he and his translation will receive, Marot clarifies that even though the psalms resemble certain pagan texts in their character and in their beauty, he can propose his translation as an acceptable devotional instrument. He positively states, "Icy sont doncq les louenges escriptes / Du roy des roys, du dieu des exercites" (vv. 65-66). ${ }^{26}$ This takes Marot's earlier statement that more or less identifies the psalms as religious poetry and further amplifies their religious nature. The psalms are more than simple poetry; if they are written praises, they begin to look more like prayers. While that is certainly the use of the text that Marot intends, something even more important resides in this text that he has chosen to translate: it is a prophetic text that ties the Old and New Testaments together, serving as an interpretative and devotional key to the reading of both and leading to a fuller understanding of Scripture. He writes,

Icy David le grand prophete Hebrieu

Nous chante, \& dit, quel est ce puissant Dieu

Qui de bergier en grand roy l'erigea,

Et sa houlette en sceptre luy changea? ${ }^{27}$ (vv. 67-70)

The poet's characterization of David has shifted along with his characterization of the psalms. His identification of David as a great Hebrew prophet initiates his discussion of what the psalms as a devotional text can accomplish. The reader has much to gain from praying with them:

Vous y orrez de Dieu la pure loy

Plus clair sonner qu'argent de fin aloy,

Et y verrez quelz maulx \& biens adviennent,

A tous ceulx la qui la rompent, \& tiennent. (vv. 71-75)

26. See Defaux's explanation of these common biblical expressions in Marot, Cinquante pseaumes, 230 n7.

27. In the 1543 edition, verse 70 ends with a full stop. See Marot, Cinquante pseaumes, 97. 
In another moment where Marot seems to set the king aside, he groups François in with all readers who should not only read but also recite the text. ${ }^{28}$ Such liberal contact with Scripture was a privilege that the Paris Faculty of Theology rarely afforded its members, much less the wider population..$^{29}$ Nevertheless, the reader can experience a rhythm and lyric qualities that give the psalms a sound purer than silver as it conveys God's law. The aural experience is accompanied by a visual one since the text also allows one to see God's justice at work. This personal and proximate seeing and hearing give a clearer sense of God, and as the next few lines affirm, they once again announce the coming of God's law in the flesh, Jesus Christ.

As Marot continues his description, the psalms come to resemble more and more an efficacious word as his letter builds toward the appearance of Christ and further emphasizes David's unique role. ${ }^{30}$ Moving beyond his earlier assimilation between François and David, Marot now translates David's role as the poet of the psalms into an effective conduit for God's voice. The Hebrew king will pronounce a word that to the unjust is menacing and to the righteous is reassuring (vv. 76-79). Furthermore, Marot writes,

Icy oyt on l'esprit de Dieu, qui crye

Dedans David, alors que David prye,

Et faict de luy, ne plus ne moins que faict

De sa musette ung bon joueur parfaict. (vv. 79-82)

The poet here gives an already established interpretation of the Catholic view of Scripture, namely, that it is the inspired word of God, and his exegesis of

28. In the 1543 edition of his translation, Marot develops this idea even further in addressing the "Dames de France." See Clément Marot, “Aux Dames de France, humble salut," in Cinquante Pseaumes en François (Geneva: Jean Gérard, 1543). According to Defaux, Marot proposes that these "saintes chansonnettes" have the power to transform the ladies who sing them, like David, into an instrument of God. See Marot, Cinquante pseaumes, 225n9.

29. Farge, 13-14.

30. For more on the importance of this role in the Reform tradition, see Dominique Vinay, "Clément Marot, Martin Luther et Pierre Caroli: aux sources des Trente premiers psalmes," in Clément Marot: "Prince des poëtes françois" 1496-1996, ed. Gérard Defaux and Michel Simonin (Paris: Honoré Champion, 1997), 419: "Conformément à l'enseignement de la Bible, David est un prophète qui prépare l'avènement du Sauveur. Sa vie et sa poésie annoncent le salut promis aux hommes et suggèrent déjà l'éternité." 
the psalms as prophecy lies well within accepted norms. ${ }^{31}$ David becomes God's perfect instrument and articulates that prophecy, giving God the opportunity to speak through him. Less within conventional boundaries, however, is Marot's suggestion that his project opens a way for God to communicate directly with God's followers, a potential transgression to some that in fact, according to Marot, justifies his and others' role in the translation and study of Scripture. While this solidifies David's prophetic status, it simultaneously carves out a corresponding role for the psalm text, which has the power to make God present. This efficacious function is apparent as the dedicatory letter reaches its climax in the first mention of Christ: "Christ y verrez, par David figuré" (v. 83). At the relative centre of the epistle, Marot explicitly identifies David with Christ, and while there is no doubt that David, as the quintessential king in the Hebrew scriptures, stands as an obvious prefiguration of the true Messiah, Marot assimilates the two more intimately. ${ }^{32}$ Here, the poet most forcefully unveils his theological and evangelical goal: to place firmly within the psalms the voice of Jesus Christ, a voice that will then be more immediate for his reader. ${ }^{33}$

François will potentially understand this assimilation between David and Christ as further praise from the poet; it rather serves to subtly usurp the king's authority as it highlights the text's ability to stand on its own and gives the air of a divine imperative behind its publication..$^{34}$ Moreover, the strong Christological character of the psalms broadens their aesthetic appeal in the service of religious devotion and an encounter with Christ; or at the very least,

31. For a discussion of where Marot's exegesis of the psalms fits, see Frank Lestringant, Clément Marot de L’Adolescence à L’Enfer (Orléans: Paradigme, 2006), 128.

32. For more on the history of this typological interpretation of Scripture and disputes surrounding it, see Erich Auerbach, "Figura," in Scenes from the Drama of European Literature (Minneapolis: University of Minnesota Press, 1984), 11-76.

33. See Corinne Noirot, "Entre deux airs": Style simple et ethos poétique chez Clément Marot et Joachim Du Bellay (1515-1560) (Paris: Hermann, 2013), 314-15. Noirot writes, "Marot traduit en décasyllabes les textes liturgiques les plus courants, dans l'optique d'une relation directe au divin par la langue naturelle" (315).

34. See Ahmed, 64. When discussing the psalm translation itself, Ahmed writes that "Francis can, at one and the same time, be the prudent king of the chosen people of France and a redeemer of mankind, and he can be like the political David and the mystical Christ." This assessment would seem to indicate that this assimilation between David and Christ is about François. As praise of the dedicatee, this may indeed be the case, but in light of his evangelical goal, Marot is pointing out that here, the reader will see and encounter Christ. 
the two of them work in concert to create a text that depicts Christ's life more clearly than even the finest Renaissance painters:

Et ce qu'il a pour noz maulx enduré,

Voyre mieulx painct mille ans ains sa venue

Qu'apres la chose escripte \& advenue

Ne le paindroient (qui est cas bien estrange)

Le tien Janet, ne le grand Miquel l'ange. (vv. 83-88) ${ }^{35}$

The comparison to Janet or Michelangelo approaches hyperbole, but in the context of the epistle and its wider goal, it appropriately distinguishes Marot's translation of the psalms from other attempts at representations of Christ after the fact. In addition to making a claim about the ability of poetic verse to compete aesthetically with the plastic arts, Marot reminds François and the reader that what his translation offers is a picture of Christ and his sufferings more vividly portrayed before the event itself than those that have the benefit of hindsight. ${ }^{36}$

These psalms will assuredly make God more present and open up new insights into Scripture, which is why in the next eighteen lines, Marot recounts many of God's wondrous deeds in the Old Testament narrative. The psalms have a direct relationship to the many ways in which God has intervened in people's lives, and at the heart of this relationship is a consciousness of the Creator's action in the world. Marot outlines what one can learn from the psalm text:
Qui bien y lit, à cognoistre il apprend
Soy, \& celluy, qui tout void \& comprend
Et y orra sur la harpe chanter

35. See Marot, Cinquante pseaumes, 231n11. Janet refers to Jean Clouet (ca. 1480-1541), a painter and valet of the chamber of the king starting in 1523. While Clouet's son, François, was also called Janet, Defaux insists that Marot could only be referring here to the father. Defaux adds that Michelangelo had been invited to France by François but never came.

36. The opposition between the plastic arts and poetry is nothing new, and during the Renaissance it was no different. For a case study in this controversy, see Roberto Campo, Ronsard's Contentious Sisters: The Paragone between Poetry and Painting in the Works of Pierre de Ronsard (Chapel Hill: University of North Carolina Press, 1998). 
Que d'estre rien, rien ne se peult vanter,

Et qu'il est tout, en ses faictz (quant au reste)

Fort admirable icy se manifeste. (vv. 89-94)

The psalms as a means of devotion help the reader to gain knowledge about one's self and God. This unsurprising consequence of their reading leads into a more definitive statement about the nature of the psalm text in specifying just how one might get to know God better through this biblical poetry. Marot constructs an antithesis between nothing and everything, not just to stress that God sees all, knows all, and is all, but also to emphasize God's capacities as creator. The repetition of "rien" with "tout" subtly draws the reader back to the Book of Genesis, where God created something out of nothing. In this way, God manifests himself and makes himself known, seen, or felt. Through a mixture of a summary of the creation narrative in Genesis and of the plagues of Egypt, Marot concludes that God gives the people these gifts to teach them how to glorify him "[e]t de quel cueur nous fault en luy fier" (v. 106). The psalms convey all of these manifestations of God's power, reaffirming what God has already done in other places in the Old Testament. The psalms become a manner of showing, one that makes God present, both through their prophetic character in announcing Jesus Christ but also in their glorification of God's deeds, made newly visible by the reader who prays them.

Marot's vision of his text as a point of more direct contact between God and the believer, seemingly shared by the many other translators of Scripture in the vernacular, did not go unnoticed, and some of the difficulties that the epistle anticipates came to pass. The Paris Faculty of Theology reacted so negatively to translations of Scripture precisely because they saw them as an instrument to introduce Protestant thought into the French mind and heart and as a suggestion that the Faculty's role in mediating God's message was vestigial. Hence, one of the surest ways to find oneself in trouble with the Paris Faculty of Theology was to translate any portion of the Bible. ${ }^{37}$ This, in turn, tended to cause political headaches for François since the translators and their defenders often called upon him to intervene on their behalf. And yet, translation, especially of the psalms, remained a preoccupation of several thinkers, scholars, and poets 
of the Renaissance. ${ }^{38}$ The psalms, whose centrality to the liturgical life of the church made them particularly sacred and, in more traditional eyes, beyond the limits of humanist or philological inquiry, simultaneously offered an enticing subject for anyone with Lutheran or Reformation sympathies. Moreover, the connection between the Old and the New Testaments, which initiates a greater proximity between the scriptural text and the everyday believer, cuts out any interpretative intermediary-namely, the Catholic Church—an obvious goal of the Reformation. The poet and translator, therefore, can help accomplish all of these goals in creating authentic devotional texts based on sacred Scripture and that facilitate the believer's knowledge of it. ${ }^{39}$

Catholic authorities were perhaps justified in their suspicions about such projects, since Catholics took quite readily to using Marot's text, despite any potential dangers it may have posed or warnings they had received..$^{40}$ Attacks on Marot's translation from Catholic polemicists, such as Artus Désiré (151079), reflect a quite reasonable fear, but whether Marot was being ideological or not, these attacks indirectly confirm that what Marot seeks to do as outlined in his dedicatory epistle was perceived as being in sympathy with ideas of the Reformation. ${ }^{41}$ Désiré, in his Combatz du fidelle papiste, first accuses Marot of bastardizing the meaning of the psalm text:

...si tresmal Marotté

Que le sens du texte a osté

Par un grand et scandaleux crime. ${ }^{42}$

38. See Bernard Roussel, "Les "Nouveaux Jérôme” (1525-1535): Les Psaumes traduits en français juxta veritatem hebraicam," in Les Réformes: Enracinement socio-culturel, ed. Bernard Chevalier and Robert Sauzet (Paris: Editions Trédaniel, 1985), 273-84.

39. For more on the Protestant desire for devotional texts, see Jacques Pineaux, introduction to Le Contrepoison des cinquante-deux chansons de Clément Marot, by Artus Désiré, vol. 1 (Geneva: Droz, 1977), 1-37, 18-31.

40. Pineaux, 17.

41. See Vinay (422) who claims that Marot's dedicatory epistle incorporates several passages from a translation of Martin Luther (1483-1546) by Pierre Caroli (1480-1550). In this sense, Marot's epistle and the subsequent translation of the psalms act as a translation of the Reformation into the French context.

42. Pineaux, 17. 
More importantly, though, this translation of the psalms acted as a vehicle for Protestant theology whose devotional character also posed a clear danger. The devotional use of the psalm translation reflected a developing Protestant liturgical identity that rejected Latin as a relic of a Catholic past. ${ }^{43} \mathrm{~A}$ vernacular translation creates a parallel liturgical life that assumes the Catholic centrality of the Psalter to worship but makes the psalms more accessible to those praying with them. For this very reason, Désiré sees the move as a threat since a mature liturgical life might contribute to the identity and permanence of an alternative confessional community. Pineaux sums up Désiré's, and therefore Catholic, fears about Marot's text: “Artus Désiré avait donc senti le danger. Permettant à la piété réformée de s'exprimer, les psaumes de Marot étaient aussi un instrument puissant de propagande, et il convenait de mettre en garde les catholiques contre la séduction de ces paraphrases qui trahissaient le texte sacré." 44

Désiré's solution to this is to rewrite Marot's translation and transform it into an anti-Protestant polemic. What is interesting, though, is how he chooses to do it. He refocuses the psalms not on Christ necessarily, but on the church. Désiré centres the text on the instrumental role of the Catholic Church in defining the faith, even when it is a question of Jesus Christ. Taking the very prophetic text from Psalm 2 that Marot seems to feature from the very beginning of his discussion of his translation, one can see in Désiré's modification his motives:

Je suis Jesus de mon pere estimé

Qui mon eglise ay si bien ordonnee

Qu'il m'en a dict tu es mon filz aymé

Engendré t'ay ceste heureuse journee. ${ }^{45}$

This affirmation of the church's relationship to Christ brooks no dissent, all the more since God affirms his relationship to Jesus because of the church's integrity. While Marot's translation of this integral psalm passage is certainly

43. See Elizabeth Hodgson, "Queen David: The Politics of 16th-Century French and English Vernacular Psalms," in Vernacular Bible and Religious Reform in the Middle Ages and Early Modern Era, ed. Wim François and August Den Hollander (Leuven: Peeters, 2017), 181-204, 186-89.

44. Pineaux, 18.

45. Artus Désiré, Le Contrepoison des cinquante-deux chansons de Clément Marot, 2 vols. (Geneva: Droz, 1977), 2:7. 
not ideal and does constitute a paraphrase, Désiré's counter-poison, as he calls it, targets Marot's improvisation of the text and any Protestant ideas that this self-proclaimed freedom may elicit.

Désiré in his reaction to Marot's translation goes too far, revealing more about Catholic fears concerning Scripture in the vernacular than about ideological designs on Marot's part. Based on the text of the dedicatory epistle itself, Marot was making an attempt, by his translation and his explanation of it, to make good on his evangelical ideals by bringing Christ closer to the reader through the reader's use of the scriptural text. It is a worthy cause that benefits the faithful, but it does not mean that Marot will leave behind any of his poetic skill. The very improvisations that more traditional Catholics find to be quasi-blasphemous rather lend a poetic credibility to the scriptural text. Marot's translation of the psalms is a prophetic and devotional text, but it is also, according to contemporary aesthetic principles and tastes, an important and refined literary work. In his dedicatory epistle, Marot promotes a cause that, while potentially abhorrent to the likes of Désiré, will constitute one of Marot's greatest gifts to his patron and the people, bringing them closer to Christ.

Amid his comments on Calvin's approach to the psalm text, Frank Lestringant writes: "Dans la perspective typologique commune à Marot et à Calvin, le destin de l'élu David, le berger fait roi, offre 'un modèle de compréhension pour la propre aventure personnelle' du croyant." ${ }^{46}$ Marot's epistle portrays an adventure in store for everyone involved: the poet, the king, and all potential readers of his psalm translation. These first thirty psalms rendered in the vernacular represent one translation among many, but what distinguishes it is the translator's vision, as articulated in the dedicatory epistle, of what the text was and what it could accomplish for any reader. In dedicating the text to François and in explaining how much his translation of the psalms fits into the king's twofold identity, Marot reminds François of his role as a wise political and spiritual leader who has the power to protect, or even advocate for, the psalms as a literary and devotional text. As a work of poetry, the psalms are finally a worthy remuneration in the series of exchanges between Marot and his patron. They offered yet another opportunity for poetic appreciation according to Renaissance ideals about the art of poetry and rhetoric. As an evangelical 
cause, the psalms, and a poetic and artful translation of them, bring new life to what, according to the poet, was becoming an increasingly distant and alien text. In Marot's own conclusion to his epistle, he writes,

Mais tout ainsi qu'avecques diligence,

Sont eclaircis par bons espritz rusez

Les escripteaulx des vieulx fragmentz usez,

Ainsi (ô roy) par les divins espritz

Qui ont soubz toy Hebrieu langaige appris,

Nous sont jectez Pseaulmes en lumiere,

Clairs, \& au sens de la forme premiere. (vv. 158-64)

Marot contrasts the light that he now sheds on these scriptural texts with the darkness into which they have fallen; with diligence and intellect, the psalms are able to come to light. The transition from dark to light, from old and worn to new and fresh, paradoxically leads back to a more primal understanding of the psalms. The simplicity to which he has returned them makes them accessible to a wider readership and to a closer and more direct relationship with Christ. Even at the end, Marot conceals his wider purpose beneath what seems to be a case for his translation on humanistic terms. Just as he uses the conventions of the epistle and the dedicatory letter to bring his text to more and more people, he subtly masks what is to be truly gained. Indeed, the translation benefits from contemporary knowledge of the original language in which they were written, a knowledge that François had a role in fostering. Nevertheless, the king must now protect and allow to come to fruition what he has made possible, that is, a new appreciation of this ancient biblical text that will reveal fresh meaning and a broader use as a devotional text. ${ }^{47}$ Marot offers up a translation and a poetic work unto itself. But the epistle's command to take up the work of David points beyond the poet's relationship to his text and to his patron, toward the text's own authority and to the manner of reform that Marot sees as a great gift to the world of letters, but more importantly to the world of faith. 